\title{
Protection of Continental Surface Waters in Senegal: What Strategy Should be Adopted for Sustainable Development?
}

\author{
Cheikh Faye* \\ Department of Geography, Laboratory of Geomatics and Environment, Senegal \\ *Corresponding author: Cheikh Faye, Department of Geography, Laboratory of Geomatics and Environment, Senegal
}

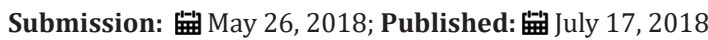

\section{Introduction}

Senegal has a rich and diversified hydrological potential. Most of the surface water reserves are located in the basins of the Senegal and Gambia Rivers, to which are added smaller rivers (Casamance and Kayanga) and small temporary flow basins. Unfortunately, these water resources are today threatened by anthropogenic actions of various origins and by the harmful effects of climate change. In addition, inadequate water management policies exacerbate water scarcity and are often not conducive to sustainable management of water resources. The protection of continental surface waters in Senegal faces major challenges. Thus, this article analyzes the main legal, administrative, technical and financial elements of a strategy to adopt for a sustainable development of continental surface waters in Senegal. The results of the analysis indicate increase in anthropogenic pressures on water bodies and rivers. Although the regulation prohibits the infringement of continental surface waters, their protection for humans and biodiversity benefit remains ineffective. In addition, means of combating pollution, methods for assessing the status of inland water bodies and their monitoring programs in Senegal are lacking, and require establishment of a new system action plan.

\section{Material and Methods}

The current study used a combined approach of observations and interviews for collection of information on the different aspects of water resources protection. The approach consisted primarily of a consultation of relevant documents (books, reports, dissertations, theses, articles, etc.). This in-depth review of literature allowed us to collect various data and information available on the pollution of water bodies in Senegal, and in areas where similar studies have been conducted. Other information used originate from the banks of the Directorate of Management and Planning of Water Resources (DGPRE), the National Agency of Statistics and Demography (ANSD), the Ministry of the Hydraulic and other ministries. In addition, interviews were conducted with some actors.

\section{Results and Discussion}

\section{Reduction of pollution at the source}

Despite the absence of binding global environmental agreements, all governments should protect water resources under their juristriction from pollution. Senegal is resolutely engaged in the management, protection and fight against pollution of water resources. Water remains an essential resource for the sustainable well-being of the population and the country generally has sufficient water resources to meet the needs of the current population. However, the availability of water in Senegal is continuously declining, both in total water quantity and per capita water availability. Deterioration of water quality is due to agricultural run-off and nutrient-laden human waste (such as nitrates and phosphates) which cause eutrophication of lakes, salinization due to irrigation and water diversions, chemicals and persistent pollutants (eg. pesticides) [1]. In Senegal, this water pollution of agricultural origin is concentrated in agricultural land uses of intense agriculture with massive fertilizer and pesticide applications, which is case in Richard Toll in United States sugarcane growing fields of the Senegalese Company of Sugar (CSS). Pollution by pesticides and fertilizers occurs mainly through irrigated and agro-industrial activities river valleys. It is noted that there are serious water quality problems caused by the residues of pesticides (pesticides, herbicides fungicides and other chemicals) discharged into the environment from drainage water of irrigated crops such as irrigated rice cultivation.

In Senegal, water management poses a confounding challenge for local authorities as well as for the Statebecause of a lack of capacity to implement an appropriate planning policy. For improved management of sanitation and water that are not yet transferred to local authorities, the State must respond to certain vital imperatives, such as ensuring that populations have easy access to drinking water and to ensure establishment of adequate sanitation 
infrastructure before the sites are inhabited. Thus, various means, plans and regulations are implemented by the public authorities to avoid or limit pollution of freshwater.

\section{Systematic assessment of the water quality status of continental surface waters}

Senegalese regulations must be updated to no longer rely on the old French system that appeared around the 1970s. During recent decades, a new system for assessing the quality of surface water has evolved in Europe [2]. A water quality monitoring network in Senegal is in its early stage or non-existent, while the importance of discharges (domestic sewage, farm wastewater pesticide application, etc.) poses problematic of monitoring water quality. It is important to implement a quality monitoring program for all water bodies and rivers. In terms of quality, we can note the heterogeneity of water quality monitoring systems. Decision makers, managers and users do not as yet place sufficient emphasis on managing water quality issues.

Increases in the population can contribute to deterioration of water quality in the event of a sanitation deficit and / or dumping of waste and wastewater directly into environment. In this way, the water sector faces challenges of sometimes poor quality of service and deterioration of water quality due to biological contamination by human waste, chemical pollutants from industries and agricultural inputs [3]. To address this challenge, development of a strategy for harmonization and networking of monitoring systems is required, along with the definition of objectives that will guide different proposals. To deal with a water quality emergency, a system for monitoring water quality of the water bodies and watercourses must be operational.To successfully assess the condition of rivers and water bodies, it is essential to define a monitoring program for continental surface water bodies, while avoiding conflict between a multitude of actors (Wetlands Waters and Forests Directorate, OMVS for the Senegal River Basin, OMVG for the Gambia River Basin, DGPRE for the Management of Water Resources in the National Territory...)[2]. These different actors do not share a common mandate [4]

\section{Financial resources}

Physicochemical and chemical analyzes as well as the evaluation of biological indices and hydromorphological parameters are expensive. Thus, the success of a continental surface water protection strategy relies mainly on the availability of financial resources. To achieve access to financial resources, it is necessary to apply the principle of 'user-payer', a principle according to which the user must assume costs related to resources and services that he uses. There is a need to review pricing rules for drinking water and irrigation. The Water Code states that the collection of water is subject to the collection of a fee, including a water quality protection fee, collected from each user connected to a collective drinking water network. industrial or agricultural (Article 16). A fee is also payable for any facility discharging effluent into a natural environment with or without a treatment plant, a fee depending on the degree of pollution and fixed at CFAF 180 per $\mathrm{kg}$ of polluting load (Interministerial Order No. 1555).

\section{Conclusion and Recommendation}

Protection of surface water in Senegal faces many flaws and requires the commitment of actions to reduce pollution at source and systematic assessment of situation of watercourses and water bodies. Regulations concerning reduction of pollution at source must be respected, the Environment and Sustainable Development Ministry has role of carrying out inspection visits of any installation likely to present a danger for the environment; that concerning assessment of situation of surface water is expected to evolve. The Directorate of Management and Planning of Water Resources (DGPRE) must be reorganized in order to be able to apply it correctly.

\section{References}

1. Belhaouari B, Belguermi A, Achour T (2017) Protection des eaux de surfaces continentales en Algérie: Quelle stratégie faut-il adopter pour les dix prochaines années? Larhyss Journal 31: 7-17.

2. Faye C (2013) Evaluation et gestion intégrée des ressources en eau dans un contexte de variabilité hydroclimatique: cas du bassin versant de la Falémé. Thèse de Doctorat. Université Cheikh Anta Diop de Dakar, Senegal, p. 309.

3. Jabeen A, Huang XS, Aamir M (2015) The Challenges of Water Pollution, Threat to Public Health, Flaws of Water Laws and Policies in Pakistan. Journal of Water Resource and Protection 7: 1516-1526.

4. Mané M (2008) Impact des activités humaines sur la qualité de l'eau du fleuve Sénégal.
Creative Commons Attribution 4.0 International License

For possible submissions Click Here

\section{Submit Article}

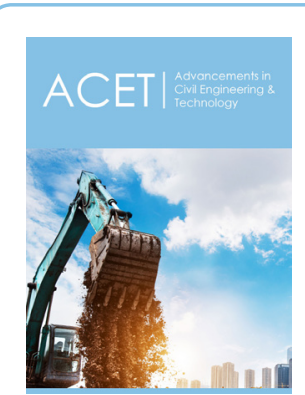

Advancements in Civil Engineering \& Technology

Benefits of Publishing with us

- High-level peer review and editorial services

- Freely accessible online immediately upon publication

- Authors retain the copyright to their work

- Licensing it under a Creative Commons license

- Visibility through different online platforms 